\title{
Vaginal Cancer pT2 TNM Finding v7
}

National Cancer Institute

\section{Source}

National Cancer Institute. Vaginal Cancer PT2 TNM Finding v7. NCI Thesaurus. Code C89463.

Vaginal cancer invading the paravaginal tissues but not the pelvic wall. (from AJCC 7th Ed.) 